INTIQAD: JURNAL AGAMA DAN PENDIDIKAN ISLAM

ISSN 1979-9950 (print) || ISSN 2598-0033 (online), http://jurnal.umsu.ac.id/index.php/intiqad DOI: 10.30596/intiqad.v12i2.5195

Vol. 12, No. 2 (December 2020)

\title{
Pendidikan Responsibility Philantropy Behaviour dan Intention To Pray Pada Siswa di Tengah Pandemi Covid-19
}

\author{
Suhardin ${ }^{*}$ \\ Fakultas Agama Islam Universitas Ibnu Chaldun (UIC) Jakarta*1 \\ *1e-mail: suhardin@yahoo.com
}

\begin{abstract}
The some studies generally explored the meaning and wisdom of prayer and the benefits of zakat, infaq and sadaqah Muslim philanthropy. This study find the relationship between the intention to pray and the responsibility philanthropic behavior of students of SMP Assyairiyah Atthahiriyah Jakarta by taking sixty recovered respondents by random sampling. From the results of data analysis, it was found that there was a very significant relationship between intention to pray and responsibility philanthropy behavior. Thus it can be concluded that building student responsibility regarding philanthropy by trying to synergize the development of a noble desire to establish prayers completely.
\end{abstract}

\section{Keyword: Responsibility Philantropy Behaviour, Intention} To Pray, COVID-19

\section{Abstrak}

Beberapa penelitian terdahulu umumnya mengekplorasi makna dan hikmah shalat dan kebermanfaatan zakat, infaq dan sadaqah sebagai philantropy muslim. Penelitian ini menemukan hubungan variabel keinginan untuk shalat (intention to pray) dengan perilaku philantropi yang bertanggungjawab (responsibility philantropy behaviour) pada siswa SMP Assyairiyah Atthahiriyah Jakarta dengan mengambil enam puluh orang responden secara random sampling. Dari hasil analisis data ditemukan bahwa terdapat hubungan yang sangat significant antara intention to pray dengan responsibility philantropy behaviour. Dengan demikian dapat disimpulkan bahwa membangun tanggungjawab siswa tentang philantropy dengan berupaya mensinergikan pembangunan keinginan yang luhur untuk mendirikan shalat secara utuh dan menyeluruh.

\section{Kata Kunci: Responsibility Philantropy Behaviour, Intention To Pray, COVID-19}

Artikel Info

Received:

28 August 2020

Revised:

20 October 2020

Accepted:

13 November 2020

Published:

03 December 2020 


\section{A. Pendahuluan}

Musibah dalam bentuk merebaknya COVID-19 keseantero dunia, telah menelan korban lebih kurang dua juta kasus. Dari laporan dua ratus sepuluh negara di dunia tercatat bahwa seratus sembilan puluh lima ribu tujuh ratus lima puluh lima orang meninggal dunia dan tujuh ratus delapan puluh satu ribu seratus sembilan orang dinyatakan sembuh. (Pan, 2020) Penyebaran Corona Virus Diseas-19 tersebut menurut pakar kesehatan melalui semburan air liur yang dihasilkan oleh percikan bersin dan batuk (droplet). Selain itu juga dapat menempel pada benda-benda yang terkontaminasi, kemudian disentuh tangan dan mengusap wajah, dengan demikian, pandemi ini merupakan penyebaran yang sangat berbahaya.

Laporan WHO (Word Health Organization) tertanggal 27 Agustus 2020 bahwa Indonesia telah menempati angka seratus enam puluh dua ribu delapan ratus delapan puluh empat kasus pengidap positif Covid-19, peringkat ketiga terbanyak di Asia. (World Health Organization, 2020) Berbagai treatment dilakukan oleh pemerintah dan masyarakat untuk mengantisipasi penyebaran yang lebih luas. Jiwa kepedulian, kegotongroyongan, solidaritas, kebersamaan, muncul di tengah masyarakat. Semua saling berbagi peran, mengambil inisiatif, berkolaborasi dengan pemerintah, untuk meringankan beban penderitaan yang dialami oleh sebagian dari anggota masyarakat yang diterpa musibah pandemi ini.

Mengantisipasi penyebaran tersebut, Pemerintah Pusat mengambil kebijakan dengan mengeluarkan Peraturan Pemerintah (PERPU) Nomor 21 Tahun 2020 tentang Pembatasan Sosial Berskala Besar Dalam Rangka Percepatan Penanganan Corona Virus Diseas-2019 (COVID-19). Pembatasan Sosial Berskala Besar paling sedikit meliputi: a. peliburan sekolah dan tempat kerja; b. pembatasan kegiatan keagamaan; dan/atau c. Pem-batasan kegiatan di tempat atau fasilitas umum. (Presiden Republik Indonesia, 2020) di Daerah Khusus Ibukota (DKI) Jakarta, Gubernur mengeluarkan PERGUB DKI Jakarta Nomor 41 Tahun 2020 Pengenaan Sanksi Terhadap Pelanggaran Pelaksanaan Pembatasan Sosial Berskala Besar Dalam Penanganan Corona Virus Disease 2019 (COVID-19) Provinsi Daerah Khusus Ibukota Jakarta. Pergub 
ISSN 1979-9950 (print) || ISSN 2598-0033 (online), http://jurnal.umsu.ac.id/index.php/intiqad DOI: 10.30596/intiqad.v12i2.5195

Vol. 12, No. 2 (December 2020)

DKI Jakarta menggariskan sanksi setiap orang yang tidak melaksanakan kewajiban menggunakan masker di luar rumah pada tempat umum atau fasilitas umum selama pemberlakuan pelaksanaan PSBB dikenakan sanksi: a. administratif teguran tertulis; b. kerja sosial berupa membersihkan sarana fasilitas umum dengan mengenakan rompi; atau c. denda administratif paling sedikit Rp 100.000,00 (seratus ribu) dan paling banyak Rp 250.000,00 (dua ratus lima puluh ribu rupiah). (PERGUB, 2020)

$$
\text { Rakyat dibatasi dalam }
$$

beraktifitas keseharian, dalam rangka menjaga, mengendalikan dan menihilkan penularan COVID-19 tersebut, sehingga konsentrasi kegiatan masyarakat dianjurkan di rumah, anak belajar di rumah, pekerja bekerja di rumah, guru mengajar di rumah, Dosen memberikan perkuliahan di rumah, dan banyak perusahaan dengan alasan cahsflow, merumahkan para karyawannya, ekonomi mengalami pelambatan yang cukup serius. Berbagai peneitian yang dilakukan terhadap dampak PSBB terhadap perekenomian masyarakat, diantaranya, hasil penelitian yang telah dirilis oleh LIPI pada bulan Mei 2020 menyatakan bahwa $50 \%$ dari responden yang dijaring hanya mampu mempertahankan ekonomi rumah tangganya selama seminggu. Justru itu mereka berusaha untuk tidak berbelanja yang melebihi kebutuhan, berusaha untuk memakan yang tersedia, berusaha mencari akses bantuan dari berbagai pihak. Penelitian ini dilakukan pada tanggal 3-12 Mei 2020 di tiga propinsi, Jakarta Banten dan Jawa Barat dengan responden sebanyak sembilan ratus sembilan belas dengan menggunakan google form. (Yayuk Hidayah, Nufikha Ulfah, 2019)

Penelitian tersebut juga merilis bahwa $44 \%$ (empat puluh empat persen) responden kehilangan pekerjaan, dirumahkan, pemutusan hubungan kerja. Pengangguran baru tersebut bertahan hidup dengan mengubah pola menu konsumsi sesuai dengan ekonomi masing-masing. Upaya lain mereka lakukan dengan makan tabungan, tetapi hanya bertahan dalam waktu yang sangat terbatas, singkat, karena tabungan juga terbatas. Untuk bertahan hidup, mereka berusah meminjam uang kerabat terdekat, tetangga, dan teman dekat.

Empati, simpati, kepedulian terhadap kondisi orang lain, perlu dibina, 
melalui pendidikan di sekolah, di rumah dan di tengah masyarakat, agar seorang anak manusia tidak hidup egoistik. Keprihatinan terhadap kesusahan yang dirasakan oleh saudara perlu menjadi awareness (kesadaran) dalam kehidupan individual amanusia. Hal ini perlu dilakukan pembiasaan, pelatihan, pendidikan sehingga menjadi karakter pada diri seseorang. Pembiasaan merupakan salah satu metode pendidikan yang sangat penting, terutama bagi anakanak. Mereka belum menyadari, dan memahami yang baik dan buruk. Mereka juga belum mempunyai kewajiban yang harus dipertanggungjawabkan seperti orang dewasa. Mereka perlu dibiasakan dengan tingkah laku, ketrampilan, kecakapan dan pola berfikir tertentu. Anak perlu dibiasakan pada sesuatu yang baik. Lalu mereka akan mengubah seluruh sifat-sifat baik menjadi kebiasaan, sehingga dengan kerelaan dapat menunaikan kebiasaan itu tanpa ada paksaan, tekanan. (Aisyahnur Nasution, 2019)

Kebiasaan melekat dalam diri seseorang, menyatu secara permanan menjadi kepribadian (personality). Kepribadian menjadi karakteristik diri, menjadi penanda dan identitas pada diri seseorang. Orang yang terbiasa melakukan yang buruk, untuk mengubah itu, diperlukan terapi khusus. Kebiasaan menjadi kepribadian, personality. Kebiasaan melaksanakan shalat, berinfak (kedermawanan), philantropy, menolong dan berbuat baik terhadap sesama, bergotong royong, hidup bersih dan mencintai kebersihan, menjaga solidaritas sosial di kalangan teman dan sesama manusia, berbuat baik kepada semua makhluk hidup ciptaan Tuhan.

Manusia sebagai makhluk sosial, saling membutuhkan, saling ketergantungan, satu individu dengan individu lainnya. saling membantu hal yang sangat ensensial dalam kehidupan bermasayrakat. Kehiduapn dan kesuksessan individu tidak bisa dilepaskan dari individu lain dan kehidupan sosial lainnya Betapapun seseorang memiliki kepandaian, namun hasil-hasil material yang diperolehnya adalah berkat bantuan pihak-pihak lain, baik secara langsung, disadari, maupun tidak. (Makki, 2019). Manusia membutuhkan manusia lain dalam hal keamanan dirinya, pertemanan dengan yang lain, eksistensi dirinya di mata yang lain, kesukaan dirinya terhadap diri lain, inilah ketergantungan manusia 
dengan manusia. Potensi kepedulian dalam bentuk saling berbagi pada diri seorang anak, perlu dikembangkan semenjak dini, sehingga menjadi kebiasaan dalam dirinya. Kebiasaan menjadi karakter, sehingga sulit untuk berubah dalam kondisi apapun.

Philantropy dalam pengertian kebiasaan memberikan sesuatu yang ada pada diri untuk kebutuhan, kehidupan, keamanan dan kebahagiaan orang perlu dibiasakan pada seseorang anak, sehingga ia hidup dalam rantai kebersamaan dengan orang lain. Philantropy dilakukan dalam kehidupan nyata di tengah-tengah lingkungan sebagai wujud pertanggung-jawaban individu, sosial dan sesama makhluk ciptaan Allah SWT. Sehingga philantropy menjadi perilaku individual yang bertanggungjawab terhadap kehidu-pan makhluk, perlu dibangun, dibina, dikembangkan baik secara internal personality maupun komunitas peserta didik di tengah lingkungan sosial, budaya dan lingkungan fisik. Kesadaran untuk berbagi, memberi, berinfak, bersedekah, berderma, berkasih sayang dengan sesama manusia dan sesama makhluk ciptaan Tuhan, akan tumbuh dan cepat berkembang apabila ia dipicu oleh spiritualisasi internal pada diri seseorang dalam bentuk kebiasaan beribadah kepada Allah SWT dalam bentuk shalat, berdoa, berpuasa, berzikir. Kesadaran spiritual seperti ini tertanam dalam diri seseorang berbentuk keinginan untuk shalat (intention to pray), suasana bathin ini akan mempengaruhi tingkat kesalehan sosial seseorang berbentuk responsibility philantropy behaviour.

Bagaimana wujud philantropy yang menjadi variabel pada sesorang berupa responsibility philantropy behaviour, penulis mencoba mengelaborasinya dalam mengupas makna philantropy tersebut secara akademik. Filantropi berasal dari bahasa Yunani: philein berarti cinta, dan anthropos berarti manusia adalah tindakan seseorang yang mencintai sesama manusia serta nilai kemanusiaan, sehingga menyumbangkan waktu, uang, dan tenaganya untuk menolong orang lain. Istilah ini umumnya diberikan pada orang-orang yang memberikan banyak dana untuk amal. Biasanya, filantropi bagian dari kebiasaan seorang kaya yang sering menyumbang untuk kaum miskin. (Sarstedt Marko \& Schloderer Matthias Peter, 2010). Kebiasaan ini umumnya 
INTIQAD: JURNAL AGAMA DAN PENDIDIKAN ISLAM

ISSN 1979-9950 (print) || ISSN 2598-0033 (online), http://jurnal.umsu.ac.id/index.php/intiqad

DOI: 10.30596/intiqad.v12i2.5195

Vol. 12, No. 2 (December 2020)

dilakukan oleh perusahaan, orang yang sudah kaya raya, ingin mengejar popularitas, atau mencuci uangnya supaya tidak dihitung sebagai wajib pajak.

Sebagian masyarakat yang sudah memiliki kemampuan lebih, kelebihan rejeki, terpanggil untuk melakukan philantropy atau disebut juga dengan charity (amal) sosial dengan berusaha berbuat kebaikan dan kasih sayang kepada sesama. Philanthropy memiliki cakupan makna yang lebih luas, progresif, terencana, bertujuan untuk kebaikan, kemaslahatan, dan kesejahteraan yang dapat diukur. Hal ini dapat dilakukan dengan melibatkan organisasi, pemerintah, perusahaan swasta, dan swadaya masyarakat. Filantropi berarti mendahulukan orang lain dari kita sendiri. Membantu orang lain bergegas sebelum diminta, baik duniawi maupun ukhrawi. (Jannah, 2014). Philanthropy perusahaan pada umumnya kegiatan yang dilakukan berdasarkan kebijakan manajemen, bagian dari tanggungjawab perusahan (coorporate responsibility) terhadap masyarakat dalam mewujudkan kesejahteraan sosial. (Narsiah, 2018)
Praktik filantropi baik di Indonesia maupun di luar negeri tidak bisa dilepaskan dari peran agama. Inspirasi keagamaan berimplikasi pada kegiatan filantropi yang kental dengan nuansa kegiatan karitatif dan pelayanan. Tradisi Kristen menyebut filantropi dengan istilah karitas, sering diterjemahkan dalam bahasa Indonesia dengan tradisi "beramal". Karitas berkembang menjadi semacam etika atau norma untuk saling tolong menolong. Konsep karitas diterjemahkan dalam aksi-aksi sosial berbasis keagamaan dengan tujuan memberikan pelayanan kepada masyarakat yang memerlukan atau dalam kesulitan. Di dalam Alkitab terdapat banyak keterangan tentang anjuran kepada para Murid Yesus untuk berbagi harta yang mereka miliki, memperluas keramah-tamahan dan pelayanan, dan untuk memperhatikan kebutuhan para pengikut mereka (Latief, 2013)

Dalam Islam dikenal dengan konsep zakat, ibadah yang berkaitan dengan harta benda. Seseorang yang telah memenuhi persyaratanya dituntut untuk menunaikannya, bukan sematamata atas dasar kemurahan hatinya, tetapi kalau terpaksa, di bawah tekanan 
INTIQAD: JURNAL AGAMA DAN PENDIDIKAN ISLAM

ISSN 1979-9950 (print) || ISSN 2598-0033 (online), http://jurnal.umsu.ac.id/index.php/intiqad

DOI: 10.30596/intiqad.v12i2.5195

Vol. 12, No. 2 (December 2020)

penguasa. (Shihab, 2009). Zakat yang harus dipikul oleh seseorang dalam merupakan salah satu ketetapan Tuhan, demikian juga halnya dengan sadaqah dan infak. Karena Allah menjadikan harta benda sebagai sarana kehidupan untuk manusia, itu sebabnya harus di arahkan guna kepentingan bersama. Zakat bagi seorang muslim memiliki dampak, pertama; mengikis habis sifatsifat kikir dalam diri seseorang, kedua, menciptakan ketenangan dan ketentraman dan ketiga, mengembangkan harta benda tersebut dalam bentuk kemanfaatannya.

Kebiasaan berinfak bagian dari indikator dari tingkat ketaqwaan seseorang kepada Allah SWT. Orang yang bertaqwa memiliki kebiasaan untuk memberikan hartanya di kala ia dalam kondisi berkelapangan dan di tengah kesulitan dalam mengumpulkan harta.

Sikap, sifat, nilai dan kebiasaan memberi, tidak bisa ditransformasikan secara instan kepada diri seseorang. Hal itu perlu dididikan semenjak usia dini, anak, remaja, dan dewasa awal. Pembiasaan inilah yang dikembangkan oleh sekolah dengan memberikan tanggungjawab. Memberi kepada seseorang adalah bentuk dari pertanggungjawaban. Tanggungjawab kehidupan nyata. Ia tidak bisa diwakilkan, diembankan, dan dibebankan kepada orang lain. Tersandang dipikulan seseorang yang tengah mengemban tanggungjawab tersebut. Rasa peduli, memberi, berbagi dipikulkan kepada individu, justru itu harus dibiasakan dalam bentuk perbuatan nyata, behaviour. Maka konsep philantropy tersebut adalah Responsibility Philantropy Behaviour, perilaku yang telah terbiasa untuk saling memberi, berbagi, baik dalam bentuk harta benda yang dimiliki maupun usaha dan tenaga terhadap orang lain sebagai sebuah pertanggungjawaban seorang makhluk ciptaan Tuhan berbuat kebaikan untuk sesama.

Kebaikan individual dalam bentuk memberi, berbagi, menolong dan memperhatikan kehidupan teman, seseorang dan seluruh makhluk ciptaan Tuhan, akan tertanam dengan kuat pada diri, apabila ia terbiasa dalam spiritualisasi lain. Ibadah shalat, puasa, zikir, dan beberapa ritual lainnya. Shalat adalah simbol hubungan manusia dengan Sang Pencipta, Allah SWT. Shalat merupakan kaifiyat yang telah digariskan oleh Allah SWT melalui 
INTIQAD: JURNAL AGAMA DAN PENDIDIKAN ISLAM

ISSN 1979-9950 (print) || ISSN 2598-0033 (online), http://jurnal.umsu.ac.id/index.php/intiqad

DOI: 10.30596/intiqad.v12i2.5195

Vol. 12, No. 2 (December 2020)

Rasulnya, dimulai dari takbiratul ihram dan diakhiri dengan salam. Terangkum dalam gerak fisik dan bacaan yang berisikan pemujaan dan pengharapan terhadap Allah. Shalat dilakukan dalam kesendirian dan dalam berkaum-kaum atau berjamaah. Shalat kewajiban individual terhadap Allah SWT ditentukan waktu dan pelaksanaannya. Kata shalat secara estimologi berarti doa, rahmat, dan istigfar. Islam telah mempersempit makna shalat sebagai kewajiban ibadah yang di dalamnya terdapat rukuk, sujud, gerakan-gerakan tertentu, dan aturanaturan baku yang tidak bisa mengubah semuanya. (Muwahidin, 2015)

Gerakan-gerakan shalat adalah tugas biologis, unsur-unsur pokok jasmani harus digerakkan, dikembangkan, punya nilai kesehatan, adab dan penghormatan pada Allah. Ucapan-ucapan (doa-doa) dalam shalat, sejak takbiratul ihram hingga salam merupakan kalimat suci sebagai lambang penghormatan dan penghargaan kepada Allah SWT. Ritual ini kita lakukan setiap hari lima kali, sehingga rasa dan hubungan batin kita tetap terjaga secara rapi dan teratur, agar hubungan kepada Allah semakin kuat (Bachtiar, 2014). Ritualistik shalat bagi seorang muslim menghubungkan diri secara vertikal kepada Allah SWT dan juga menghubungkan diri dengan diri lainnya secara horizontal berupa solidaritas sosial. Maka shalat berjamaah dianjurkan oleh Nabi. Shalat berjamaah lebih utama dibandingkan dengan shalat sendirian, dalam ukuran kuantitatifnya lebih utama sebesar dua puluh tujuh kali lipat dibandingkan dengan shalat sendiri. Pada shalat jamaah terjadi komunikasi intensif antar individual dalam sebuah komunitas, sehingga kepentingan dan kegelisahan seorang individu akan dapat tercairkan dalam pelaksanaan ibadah shalat jamaah.

Shalat merupakan jalan spiritualisasi seseorang menuju khaliknya. Shalat dijadikan media langsung berkomunikasi dengan Allah SWT. Perwujudan dari ketaqwaan, kepatuhan seorang hamba terhadap Allah dengan ketertiban dan ketaraturannya melaksanakan ibadah shalat. Ibadah shalat pelaksanaannya diperlukan pendidikan, pembinaan, pembiasaan, semenjak dari kecil sehingga ia telah dewasa. Melaksanakan shalat tidak bisa langsung menjadi kesadaran yang tinggi dengan sendirinya, ia membutuhkan pendidikan, pengajaran, 
INTIQAD: JURNAL AGAMA DAN PENDIDIKAN ISLAM

ISSN 1979-9950 (print) || ISSN 2598-0033 (online), http://jurnal.umsu.ac.id/index.php/intiqad

DOI: 10.30596/intiqad.v12i2.5195

Vol. 12, No. 2 (December 2020)

pelatihan dan pembiasaan. Sehingga jika mereka sudah terbiasa shalat semenjak kecil, tentunya akan mudah bagi mereka untuk menunaikan kewajiban-kewajiban agama mereka ketika menginjak masa baligh (Mahmudin, 2018).

$$
\text { Shiddieqy mendefinisikan }
$$
kualitas shalat yaitu intensitas, konsentrasi, keseriusan seseorang dalam menghadapkan hati (jiwa) kepada Allah dan mendatangkan takut kepada-Nya, serta menumbuhkan di dalam jiwa rasa keagungan, kebesaran, dan kesempurnaan kekuasaan-Nya. Jika saja manusia bangun tidur pada waktu subuh dan mengawali dengan shalat subuh yang baik tentu saja aktivitas-aktivitas berikutnya akan berjalan dengan lancar. Hal ini disebabkan karena aktivitas manusia diawali dengan kondisi psikologis yang baik. Jadi dapat dikatakan bahwa kualitas shalat subuh dapat meningkatkan kualitas hidup jika dilakukan secara konsisten (Ridho, 2019). Dalam penelitian Ridho terkait dengan efektifitas shalat subuh dalam kesuksessan seseorang berkarya, beraktivitas dan berusaha dalam masa selanjutnya sampai malam hari, dibandingkan dengan yang tidak shalat subuh, terlihat efektif, terutama dalam hal ketenangan bathin dalam menjalankan kehidupan.

Shalat hubungan langsung jarak dekat antara hamba dengan Khalik. Dalam shalat semua permasalahan yang dialami oleh seorang hamba akan dapat cair, terpecahkan, membuat hati menjadi tenang. Optimisme terbangun, harapan kembali ada, tujuan dapat dicapai, citacita dapat digapai, asa kembali tersambung. Kekerasan hati menjadi lunak, kecongkakan akan terkulai, layu bersama tuma'ninahnya ibadah shalat. Dengan shalat yang khusyu' orang akan mendapatkan ketenangan jiwa, karena merasa dirinya dekat dengan Allah SWT dan memperoleh ampunan-Nya (Nurlaeli Mafrukha, 2009). Ibadah shalat menentramkan bathin mendatangkan optimisme seseorang dalam menjalankan kehidupan, kecerahan spiritual seseorang dalam menghadapi berbagai permasalahan kehidupan.

Mendirikan shalat tidak bisa dengan instan langsung mengerjakan, melaksanakan dengan sebaik-baiknya, ia perlu pendidikan, pengajaran, pelatihan, pembinaan dan pembiasaan, semenjak dari kecil, anak-anak, remaja, dan dewasa awal sampai kepada masa tua. Amat sedikit orang yang masa kecil 
INTIQAD: JURNAL AGAMA DAN PENDIDIKAN ISLAM

ISSN 1979-9950 (print) || ISSN 2598-0033 (online), http://jurnal.umsu.ac.id/index.php/intiqad

DOI: 10.30596/intiqad.v12i2.5195

Vol. 12, No. 2 (December 2020)

tidak shalat dan dewasa dapat akan lebih terpanggil untuk melaksanakan shalat secara tertib. Tetapi melaksanakan shalat dibandingkan ada beberapa orang yang mengalami konversi spiritual, sekalipun masa kecilnya penuh dengan hal-hal yang kurang baik, tetapi setelah dewasa datang kesadaran untuk mengerjakan kebaikan dengan sebanyak-banyaknya. Mendirikan shalat perlu motivasi dari dalam diri seseorang berupa keinginan yang dalam, keinginan yang luhur untuk mengerjakan shalat, berdasarkan pengetahuan dan pengalaman spiritualnya. Keinginan untuk mengerjakan shalat berawal dari kebiasaan awal dimasa kecil, kesadaran yang timbul akibat pengetahuan terhadap kemanfaatan shalat dalam kehidupan. Keutamaan shalat dalam tata pergaulan di tengah-tengah masyarakat. Keberkahan hidup orang-orang yang mengerjakan shalat. Dan dahsyatnya shalat dalam kesuksessan kehidupan seseorang.

Keinginan untuk shalat (intention to pray) berangkat dari awarenes (kesadaran) bahwa shalat merupakan sebuah kewajiban bagi seorang dewasa muslim yang tidak bisa ditinggalkan sekalipun ada uzur (halangan). Orang yang memiliki keinginan (intention) dengan orang yang tidak berikeinginan. Keterpanggilan jiwa untuk shalat berangkat dari hati yang dalam, tetapi pada perjalanannya seseorang yang mengerjakan shalat, menikmati keberkahan shalat tersebut dalam kehidupan nyata di tengah-tengah masyarakat. Orang yang mengerjakan shalat lebih dipercaya dibandingkan dengan orang yang tidak mengerjakan shalat, orang yang shalat lebih solider dibandingkan dengan orang yang tidak shalat, orang shalat lebih bersih dibandingkan dengan yang tidak shalat, orang shalat lebih mudah dalam menjalankan kehidupan dibandingkan dengan yang tidak shalat. Keutamaan ini akan dirasakan oleh orang yang mengerjakan shalat.

Dengan kesadaran terhadap keber-hakahan, kemanfaatan, dan efek shalat dalam kehidupan, sehingga dalam beberapa peneltian, shalat memiliki hubungan dengan berbagai variabel. Diantaranya penelitian Ulyan yang melihat bahwa shalat apabila dijelaskan dari sudut pandang vertikal yaitu nilai esoteris (teks suci) dipahami sebagai media komunikasi antara "hamba" 
ISSN 1979-9950 (print) || ISSN 2598-0033 (online), http://jurnal.umsu.ac.id/index.php/intiqad

DOI: 10.30596/intiqad.v12i2.5195

Vol. 12, No. 2 (December 2020)

dengan "Khaliq". Tujuannya adalah sebagai bukti ketaatan hamba dengan perintah sakral Tuhan, karena salah satu tugas seorang muslim sejati adalah menghambakan diri kepada Sang Maha Kuasa sebagaimana yang telah ditetap dalam syari'at. Disatu sisi shalat apabila dijelaskan dari sudut pandang sosial politik (eksoteris) memiliki banyak nilainilai yang terkadung di dalamnya yang nantinya sebagai acuan untuk mencari jawaban atas problematika kehidupan yang sudah mulai bergeser ke arah disintegrasi moral (dekadensi moral). Sikap dan gerakan dalam shalat dilakukan dengan tertib namun diluar shalat ternyata masih tidak tertib. Shalat ternyata tidak hanya mengajarkan tentang kepatuhan kepada Sang Pencipta, tapi di aspek lain mengajarkan kepatuhan kepada sesama manusia. Salah satu nilai sosial politik dalam shalat adalah antara imam dan makmun terjadi kerja sama yang sangat teratur, adil, disiplin, jujur dan toleransi (Nasri, 2011).

Ulyan melihat bahwa shalat berkaitan dengan esoteris, hubungan dengan khaliq. Esoteris mengandung multi nilai, ketertiban, kepatuhan, kedisiplinan, kejujuran, kepedulian dan toleransi. Shalat juga memberikan effect terhadap kepedulian seseorang terhadap orang lain. Orang yang memiliki rasa keinginan untuk mendirikan shalat dan mengaplikasikan nilai-nilai shalat dalam kehidupan sosial kemasyarakatan, niscaya dia akan memiliki tanggungjawab berbuat untuk kebaikan terhadap sesama muslim, sesama manusia (kemanusia), berbuat untuk kemaslahatan alam (basyariah).

Dengan demikian terlihat bahwa keinginan untuk menegakkan shalat dalam hal ini membiasakan dan mengerjakan hal-hal yang ma'ruf. Nilai ini ditanamkan pada anak terutama di usia anak dan remaja sebuah sikap keinginan yang kuat untuk menjaga shalatnya dan menjaga nilai-nilai shalatnya dalam kehidupan sosial kemayarakatan inilah yang menjadi variabel intention to pray. Variabel ini akan secara langsung berdampak pada perilaku yang bertanggungjawab untuk melestarikan kebiasaan berbagi, memberi, memperhatikan dan berbuat untuk manusia dan kemanusiaan dalam bentuk philantropy, inilah yang menjadi variabel responsibility philantropy behaviour. Dengan demikian intention to pray berhubungan (berkorelasi) positif 
INTIQAD: JURNAL AGAMA DAN PENDIDIKAN ISLAM

ISSN 1979-9950 (print) || ISSN 2598-0033 (online), http://jurnal.umsu.ac.id/index.php/intiqad

DOI: 10.30596/intiqad.v12i2.5195

Vol. 12, No. 2 (December 2020)

dengan responsibility philantropy

Philantropy Behaviour dilakukan dengan

behaviour.

\section{B. Metode Penelitian}

Metode Penelitian ini adalah survey (Gall., 1983) dengan korelasional variabel Intention To Pray sebagai variabel $X$ dan Responsibility Philantropy Behaviour sebagai variabel Y.

Penelitian ini bertujuan untuk mengetahui hubungan antara Intention To Pray dengan Responsibility Philantropy Behaviour. Peneliti berusaha mengembangkan konstruksi Intention To Pray dalam defenisi yang konstruktif dengan menggunakan pola berpikir deduktif (Gall., 1983), yang menangkap makna pada kajian konseptual, sehingga menemukan beberapa indikator terkait dengan Intention To Pray dan membangun kisikisi serta mengindentifikasi butir-butir instrumen pengukuran terhadap Intentuion To Pray. Instrumen dilakukan analisis validitas teoritik dan validitas empiric, (Djaali \& Muljono, 2008). Setelah melalui tahapan kalibrasi sehingga akhirnya layak untuk dijadikan pengukuran Intention To Pray. Demikian juga dengan variabel Responsibility

metode dan perlakuan sama seperti perlakuan yang sama dilakukan terhadap variable Intention To Pray.

Instrumen disebarkan kepada enam puluh orang responden yang dijadikan sampling pada sekolah SMP Assyairiyah Atthahiriyah Jakarta, diambil menggunakan teknik random sampling. (Downy, 2004) Instrumen yang sudah dinyatakan valid, di konversi menjadi google form disebarkan melalui whatsap kepada masing-masing responden. Responden membalasnya kembali kepada peneliti melalui account peneliti. Dari jawaban responden terhadap instrumen yang tersebar, penelit berusaha melakukan analisis deskriptif variabel Intention To Pray (ITP) dan variabel Responsibility Philantropy Behaviour (RPB), analisis infrensial (Downy, 2004) hubungan ITP dengan RPB. Sebelum melakukan analisis infrensial, dilakukan uji persyaratan analisis, normalitas variabel ITP, Homogenitas antara variabel ITP dengan RPB, Linieritas Variabel ITP. Setelah semua persyaratan analisis dipenuhi, dilakukan analisis statistik inferensial Uji Regresi ITP dengan RPB. Uji signifikansi regresi ITP dengan RPB. Uji Korelasi ITP dengan 


\section{INTIQAD: JURNAL AGAMA DAN PENDIDIKAN ISLAM}

ISSN 1979-9950 (print) || ISSN 2598-0033 (online), http://jurnal.umsu.ac.id/index.php/intiqad

DOI: 10.30596/intiqad.v12i2.5195

Vol. 12, No. 2 (December 2020)

RPB, dan uji signifikansi korelasi ITP dengan RPB serta Uji determinasi ITP terhadap RPB, untuk melihat konstribusi ITP terhadap RPB.

\section{Hasil dan Pembahasan}

Dari hasil pengolahan nilai pada variabel Responsibility Philantropy Behaviour diperoleh angka jumlah responden 60 (enam puluh), Mean 74,03 (tujuh puluh empat koma nol tiga), Standar Error of mean 1,255 (satu koma dua lima-lima), Median 74,00 (tujuh puluh empat koma nol), Mode 80,00 (delapan puluh koma nol), Standar Deviasi 9,73 (sembilan koma tujuh puluh tiga), Variance, 94,54 (sembilan puluh empat koma lima puluh empat), Range 44,00 (empat puluh empat koma nol), Nilai Terendah 51,00 (lima puluh satu koma nol), Nilai Tertinggi 95,00 (sembilan puluh lima koma nol) dan total nilai 4.442 (empat ribu empat ratus empat puluh dua).

Peneliti berusaha mendeskripsikan dalam bentul tabulasi nilai sebagai berikut.

Tabel 1. Distribusi Frekuensi Variabel Y

\begin{tabular}{|c|c|c|c|c|c|c|}
\hline No. & $\begin{array}{l}\text { Kelas } \\
\text { Interval }\end{array}$ & $\begin{array}{c}\text { Batas } \\
\text { Bawah }\end{array}$ & $\begin{array}{l}\text { Batas } \\
\text { Atas }\end{array}$ & $\begin{array}{c}\text { Frekuensi } \\
\text { Absolut }\end{array}$ & $\begin{array}{c}\text { Frekuensi } \\
\text { Relatif }\end{array}$ & $\begin{array}{l}\text { Frekuensi } \\
\text { Kumulatif }\end{array}$ \\
\hline 1. & $50-56$ & 49,5 & 56,5 & 2 & $3,3 \%$ & $3,3 \%$ \\
\hline 2. & $57-63$ & 56,5 & 63,5 & 6 & $10,0 \%$ & $13,3 \%$ \\
\hline 3. & $64-70$ & 63,5 & 70,5 & 12 & $20,0 \%$ & $33,3 \%$ \\
\hline 4. & $71-77$ & 70,5 & 77,5 & 20 & $33,3 \%$ & $66,6 \%$ \\
\hline 5. & $78-84$ & 77,5 & 84,5 & 10 & $16,6 \%$ & $83,2 \%$ \\
\hline 6. & $85-91$ & 84,5 & 91,5 & 7 & $11,6 \%$ & $94,8 \%$ \\
\hline 7. & $92-98$ & 91,5 & 98,5 & 3 & $5,0 \%$ & $99,8 \%$ \\
\hline \multicolumn{4}{|c|}{ Jumlah } & 60 & $100 \%$ & $100 \%$ \\
\hline
\end{tabular}

Dapat divisualisasikan dalam bentuk grafik sebagai berikut:

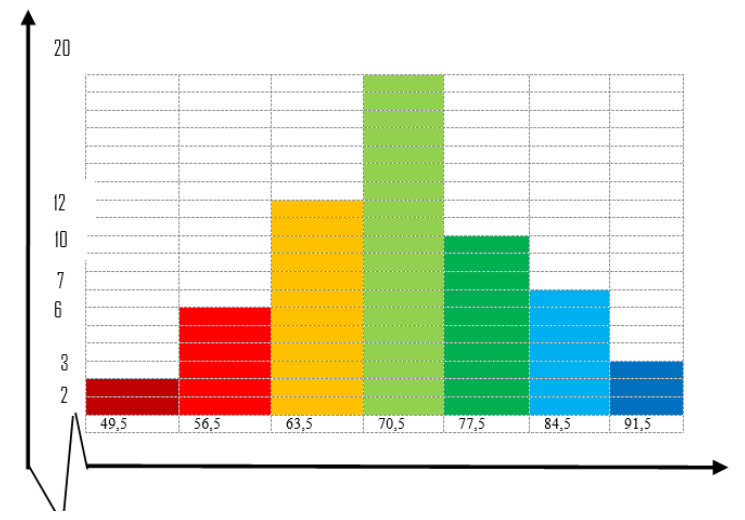

Gambar 1. Grafik Distribusi Nilai Variabel Y 
INTIQAD: JURNAL AGAMA DAN PENDIDIKAN ISLAM

ISSN 1979-9950 (print) || ISSN 2598-0033 (online), http://jurnal.umsu.ac.id/index.php/intiqad

DOI: 10.30596/intiqad.v12i2.5195

Vol. 12, No. 2 (December 2020)
Dari hasil pengolahan nilai pada variabel Intention To Pray diperoleh scoring dari jumlah responden 60 (enam puluh), Mean 71,36 (tujuh puluh satu koma nol tiga puluh lima), Standar Error of mean 1,418 (satu koma empat satu delapan), Median 70,00 (tujuh puluh koma nol), Mode 84,00 (delapan puluh empat koma nol), Standar Deviasi 10,982 (sepuluh koma sembilan delapan dua), Variance, 120,604 (seratus dua puluh koma enam kosong empat), Range 53,00(lima puluh tiga koma nol), Nilai Terendah 41,00 (empat puluh satu koma nol), Nilai Tertinggi 94,00 (sembilan puluh empat koma nol) ) dan total 4.281 (empat koma dua delapan satu). Berikut ini disajikan tabel tentang tabulasi nilai.

Tabel 2. Distribusi Frekuensi Variabel X

\begin{tabular}{|c|c|c|c|c|c|c|}
\hline No. & $\begin{array}{l}\text { Kelas } \\
\text { Interval }\end{array}$ & $\begin{array}{c}\text { Batas } \\
\text { Bawah }\end{array}$ & $\begin{array}{c}\text { Batas } \\
\text { Atas }\end{array}$ & $\begin{array}{c}\text { Frekuensi } \\
\text { Absolut }\end{array}$ & $\begin{array}{c}\text { Frekuensi } \\
\text { Relatif }\end{array}$ & $\begin{array}{l}\text { Frekuensi } \\
\text { Kumulatif }\end{array}$ \\
\hline 1. & $40-47$ & 39,5 & 47,5 & 1 & $1,6 \%$ & $1,6 \%$ \\
\hline 2. & $48-55$ & 47,5 & 55,5 & 2 & $3,3 \%$ & $4,9 \%$ \\
\hline 3. & $56-63$ & 55,5 & 63,5 & 10 & $16,6 \%$ & $21,56 \%$ \\
\hline 4. & $64-71$ & 63,5 & 71,5 & 20 & $33,3 \%$ & $54,89 \%$ \\
\hline 5. & $72-79$ & 71,5 & 79,5 & 13 & $21,6 \%$ & $76,56 \%$ \\
\hline 6. & $80-87$ & 79,5 & 87,5 & 9 & $15,0 \%$ & $91,56 \%$ \\
\hline 7. & $88-95$ & 87,5 & 95,5 & 5 & $8,3 \%$ & $99,89 \%$ \\
\hline \multicolumn{4}{|c|}{ Jumlah } & 60 & $100 \%$ & $100 \%$ \\
\hline
\end{tabular}

Dapat divisualisasikan dalam bentuk grafik sebagai berikut:

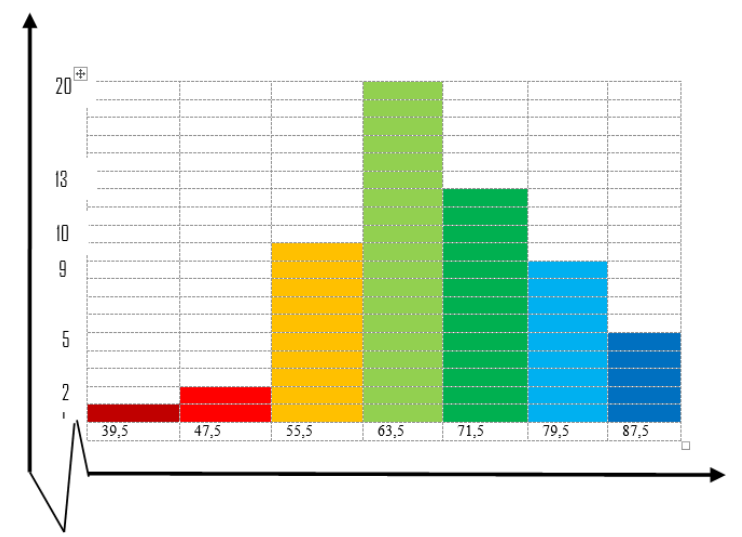

Gambar 2. Grafik Distribusi Nilai Variabel X

Persyaratan analisis peneliti lakukan uji menggunakan kolmogorove-smirnove, normalitas variabel Responsibility diperoleh asym sign sebesar $=0,76>0,05$ Philantropy Behaviur dengan dan pada varibel Intention To Pray 
INTIQAD: JURNAL AGAMA DAN PENDIDIKAN ISLAM

ISSN 1979-9950 (print) || ISSN 2598-0033 (online), http://jurnal.umsu.ac.id/index.php/intiqad

DOI: 10.30596/intiqad.v12i2.5195

Vol. 12, No. 2 (December 2020)

sebesar $0,53>0,05$, dengan demikian kedua kelompok data variabel $\mathrm{X}$ dan variabel $\mathrm{Y}$ berdistribusi normal. Homogenitas antara variabel $\mathrm{X}$ dengan Y pada uji liliford dengan bantuan SPSS diperoleh signifikansi $0,02<0,05$ yang menyatakan bahwa data $\mathrm{X}$ dengan $\mathrm{Y}$ memiliki homogenitas.

Setelah melakukan persyaratan analisi tersebut, peneliti melakukan uji regresi dalam rangka melihat hubungan antara Intention To Pray sebagai variabel $\mathrm{X}$ dengan Responsibility Philantropy Behaviour sebagai variabel Y. Dalam perhitingan diperoleh gambaran resresi dalam bentuk $\bar{Y}=62,58+0,30 x$. Hal ini menggambarkan bahwa pertambahan skoring Intention To Pray sebesar satu akan menambah Responsibility Philantropy Behaviour siswa sebesar 0,30 pada konstanta 62,58. Intention To Pray pada siswa memberikan pengaruh terhadap Responsibility Philantropy Behaviour.

Dalam uji korelasi yang dilakukan dengan uji korelasi product moment dibantu oleh SPSS diperoleh keofisiensi korelasi sebesar $r_{\text {hitung }}=0,340$ signifikansi $\quad 0,008<0,01 * * \quad$ dengan demikian signifikasi sangat signifikan.
Koefisien korelasi Intention To Pray sebagai variabel $\mathrm{X}$ dengan Responsibility Philantropy Behaviour sebagai variabel Y sangat signifikan. Koefisien determinasi antara Koefisien korelasi Intention To Pray sebagai variabel $\mathrm{X}$ dengan Responsibility Philantropy Behaviour sebagai variabel Y sebesar 11,56\% artinya Responsibility Philantropy Behaviour pada diri siswa dipengaruhi oleh Intention To Pray yang ada padanya.

Dari temuan penelitian ini telah terbukti secara empirik bahwa variabel intention to pray memiliki hubungan yang sangat signifikan dengan responsibility philantropy behaviour dengan koefisien korelasi sebesar $\mathrm{r}_{\text {hitung }}=0,340 \quad$ sangat signifikan $0,008<0,01^{* *}$. Hal ini dapat ditangkap maknanya bahwa intention to pray memiliki hubungan yang sangat signifikan dengan responsibility philantropy behaviour. Demikian juga dalam bentuk regresi terlihat dalam gambaran $\bar{Y}=62,58+0,30 x$. Hal ini memberikan makna bahwa penambahan scoring intention to pray akan memberikan penambahan scoring kepada responsibility philantropy behavuour pada konstanta 62,58. Dalam 
ISSN 1979-9950 (print) || ISSN 2598-0033 (online), http://jurnal.umsu.ac.id/index.php/intiqad

DOI: 10.30596/intiqad.v12i2.5195

Vol. 12, No. 2 (December 2020)

arti yang sesungguhnya bahwa intention to pray memiliki keterkaitan yang sangat signifikan dengan responsibility philantropy behaviour. Pada koefisien determinasi ditemukan angka 11,56\% dalam pengertian bahwa intention to pray memiliki pengaruh terhadap responsibility philantropy behaviour sebesar $11,56 \%$ variabel lain yang mempengaruhi responsibility philanthropy behaviour perlu dilakukan kajian dan penelitian lain, sehingga diperlukan penelitian asosiatif multi variabel dan dilakukan analisis liserial, dalam rangka melihat beberapa variabel yang mempengaruhi responsibility philantropy behaviour tersebut selain dari intention to pray. Pada penelitian ini hanya terbatas pada intention to pray.

Di tengah pandemi covid-19 yang memberikan efek terbatasnya gerak dan langkah seseorang untuk menggali dan mencari pintu-pintu rejeki, dibutuhkan kesadaran yang dalam terhadap pentingnya implementasi responsibility philantropy behaviur secara nyata dalam kehidupan sosial. Membangun kesadaran responsibility philantropi behaviur tersebut perlu dibiasakan semenjak masa pendidikan terutama di sekolah-sekolah.
Pembangunan tersebut dilakukan dengan langkah. Pertama, menanamkan kesadaran tanggungjawab individual dan sosial terhadap individu siswa tentang pentingnya berbagi dalam kehidupan nyata. Tidak ada manusia yang dapat bertahan hidup tanpa bantuan orang lain. Tidak ada kesuksesan yang diraih oleh seseorang yang tengah menempati puncak kehiduapan, tanpa bantuan orang lain, baik disadarinya maupun tidak. Konstribusi seseorang terhadap orang lain nyata dan bermakna dalam kehidupan, justru itu perlu dikembangkan, didik, diajarkan, ditanamkan dan dibiasakan, dalam karakteristik personal manusia, dengan pendekatan pendidikan yang terprogram dan terukur di sekolah.

Kedua, membangun responsibility philantropi behaviour tidak bisa independent, berdiri sendiri, tanpa dipengaruhi oleh variabel lainnya. Variabel yang terbukti mempengaruhinya adalah intention to pray. Hal ini sudah dibuktikan dalam penelitian ini. Intention to pray individu memiliki hubungan yang sangat signifikan dengan responsibility philantropi behaviour, justru itu untuk membangun responsibility philantropi 
INTIQAD: JURNAL AGAMA DAN PENDIDIKAN ISLAM

ISSN 1979-9950 (print) || ISSN 2598-0033 (online), http://jurnal.umsu.ac.id/index.php/intiqad

DOI: 10.30596/intiqad.v12i2.5195

Vol. 12, No. 2 (December 2020)

behaviour juga perlu dibangun, dikembangkan, dibina dan dibiasakan intention to pray kepada siswa. Pengembangannya dapat dilakukan dalam bentuk kegiatan nyata di sekolah (1) membiasa-kan shalat jamaah di sekolah dalam ben-tuk peraturan sekolah; (2) memperhatikan dengan sungguhsungguh kebiasaan anak dalam mengerjakan shalat lima waktu dalam bentuk jadwal kegiatan shalat privat anak; (3) membiasakan shalat duha di sekolah sebagai penyegaran pada anak dalam mengikuti pembelajaran; (4) meng-organisasi pelaksanaan ibadah shalat jum'at dalam bentuk manajemen sekolah dengan melibatkan siswa secara aktif dan bertanggungjawab; menyelenggarakan pelaksanaan shalat subuh berjamaah dalam bentuk kegiatan sekolah yang ter-program, diikuti dengan kegiatan sosial lainnya.

Ketiga, kebiasaan terhadap mem-beri kepada orang lain, bagian dari pang-gilan jiwa, bukan seperti umumnya phi-lantropi yang kita temukan, yaitu individu pemberi uang, waktu atau pemberian melalui warisan, yayasan, organisasi phi-lantropi dan bisnis yang dilakukan oleh perusahaan, bagian dari manajemen perusahaan karena dipaksa oleh Undang-Undang Negara. Jika kita fokus pada lanskap organisasi filantropi, kita akan bertemu dengan yayasan penggalangan dana (seperti World Wildlife Fund), badan amal, yayasan yang diberkahi (seperti Wellcome Trust di Inggris atau "Bertelemanns Stiftung" di Jerman) dan lotere tujuan baik. (Schuyt et al., 2010) memberi kepada orang lain, wujud dari ketaqwaan kepada Allah SWT. Orang yang bertaqwa membiasakan dirinya untuk memberi kepada orang lain dikala lagi mengalami kemudahan dan di tengah mengalami kesusahan. Covid-19 mendera semua bangsa di dunia, membuat semua manusia sehingga mengalami kesusahan di sana sini dalam bentuk keunikan tersen-diri sesuai dengan pengalaman individual masing-masing, maka momentum ini memanggil manusia untuk peduli dengan kemanusiaan dalam bentuk responsibility philantropi behaviour. Kesulitan ini memanggil dan memaksa manusia harus peduli, perhatian dan berbagi untuk manu-sia dan kemanusiaan.

Keempat, philantropi memberikan keberuntungan yang cukup jauh dan besar pada seseorang. Banyak para aktor mela-kukan philantropi 
ISSN 1979-9950 (print) || ISSN 2598-0033 (online), http://jurnal.umsu.ac.id/index.php/intiqad

DOI: 10.30596/intiqad.v12i2.5195

Vol. 12, No. 2 (December 2020)

berbiaya mahal, karena mereka jadikan sebagai momentum untuk popularitas dan kegiatan yang bersifat pencitraan diri, tetapi philantropi akan mendapatkan maknanya yang hakiki berbiaya lebih rendah, menghasilkan lebih banyak manfaat. (Rahim et al., 2011) hal tersebut akan terwujud apabila yang melakukannya tulus dan ikhlas karena Allah SWT. Keikhlasan kepada Allah akan mendatangkan jalan yang lurus dan menghasilkan kemanfaatan yang besar pada diri seseorang dalam bentuk kebai-kan nyata yang tidak terduga dan tidak terperhitungkan semenjak awalnya, tetapi akan dinikmati oleh para mukhlisin tersebut.

\section{Kelima responsibility}

philantropy behaviour merupakan amal shaleh, kesalehan sosial pada diri individu manusia, pembangunannya pada diri personal manusia perlu diberengin dengan ibadah lainnya, terutama ibadah shalat. Kesalehan individual akan berpengaruh dan berkaitan langsung dengan kesalehan sosial. Antara kesalehan individual dan kesalehan sosial integritif, terpadu dan berhimpitan dalam diri seorang individu dan personal manusia. Tindakan pembinaan, pendidikan, pengembangan dilakukan dengan keterpaduan, dalam bentuk program yang nyata berkesinambungan (sustuinable), bertahap (gradual), teragenda dan terukur. Sekolah lembaga strategis untuk melakukan hal ini, tetapi harus dengan keinginan yang luhur oleh pimpinan sekolah dan semua civitas keluarga besar sekolah, bersatu padu untuk menciptakan, membangun, dan mengembangkan intention to pray dan responsibility philantropy behaviour dalam rangka menjawab permasalahan kebangsaan ini.

Keenam, firman Allah SWT dalam beberapa ayat di beberapa surat dalam al-Qur'an yang mengaitkan antara shalat dan amal shaleh banyak sekali, diantaranya pada surat al-Anfal ayat 3 "orang-orang yang melaksanakan shalat dan yang menginfakkan sebagian dari rejeki yang kami berikan kepada mereka". Shalat dan philantropy berintegrasi dalam kebaikan seseorang. Hal ini telah terbukti bahwa intention to pray dan responsibility philantropy behaviour memiliki hubungan yang signifacant, sehingga ayat qauliyah Allah SWT dengan ayat kauniyah Allah secara empirik telah terbukti secara nyata. Firman Allah dan ilmu 
ISSN 1979-9950 (print) || ISSN 2598-0033 (online), http://jurnal.umsu.ac.id/index.php/intiqad DOI: 10.30596/intiqad.v12i2.5195

Vol. 12, No. 2 (December 2020)

pengetahuan tidak terpisahkan, dan terbukti kebenarannya.

\section{Simpulan}

Dari temuan dan analisis serta pembahasan yang dilakukan di atas dapat disimpulkan bahwa untuk membangun, mengembangkan, mendidik, mengajarkan dan membina kebiasaan responsibility philantropy behaviour pada diri seseorang tidak bisa dipisahkan dengan melakukan yang sama juga terhadap intention to pray, karena keduanya memiliki hubungan yang sangat signifikan. Kedua variabel ini perlu ditanamkankan semenjak usia pendidikan, dengan jalan mendidik, mengajarkan, membina, dan membiasakan intention to pray dan responsibility philantropy behaviour kepada peserta didik.

\section{E. Daftar Pustaka}

Aisyahnur Nasution. (2019). Metode Pembiasaan Dalam Pembinaan Shalat Berjamaah dan Implikasinya terhadap Penanaman Budaya Beragama Siswa SMP Negeri 2 Kabawetan. Al-Bahtsu, 4(1), 11-23. Bachtiar, E. (2014). Shalatsebagai Media Komunikasi
Transendental. Konseling Religi :

Jurnal Bimbingan Konseling Islam, 5(2), 385-400.

Djaali, P. M., \& Muljono, P. (2008). Pengukuran Dalam Bidang Pendidikan: Jakarta. Grasindo.

Downy, S. (2004). Statistics for Research (pertama). Wiley Interscince.

Gall., W. R. . M. D. (1983). Educational Research. Longman.

Jannah, L. (2014). Pengaruh Religiusitas Dan Pendapatan Orang Tua Terhadap Perilaku Filantropi Mahasiswa Fakultas Ilmu Dakwah Dan Ilmu Komunikasi Uin Syarif Hidayatullah Jakarta.

Latief, H. (2013). Melayani Umat. Gramedia Pustaka Utama.

Mahmudin, M. (2018). Tanggung Jawab Dan Peran Orang Tua Dalam Pendidikan Shalat Bagi Anak Usia Dini. Al-Madrasah: Jurnal Pendidikan Madrasah Ibtidaiyah, $3(1)$, $27-44$. https://doi.org/10.35931/am.v0i0.68 Makki, M. (2019). Tafsir Ayat-Ayat Zakat Sebagai Penguat Konsep 
INTIQAD: JURNAL AGAMA DAN PENDIDIKAN ISLAM

ISSN 1979-9950 (print) || ISSN 2598-0033 (online), http://jurnal.umsu.ac.id/index.php/intiqad

DOI: 10.30596/intiqad.v12i2.5195

Vol. 12, No. 2 (December 2020)

Filantopi Ekonomi Keummatan. A $\alpha \propto \eta, 8(5), 55$.

Muwahidin, A. (2015). Hubungan antara intensitas shalat Tahajud dengan Pengalaman Spiritualisasi Santri Pondok Pesantren Al-Qudsy Kudus. In IAIN Walisongo (Vol. 151, Issue 2013).https://doi.org/10.1145/31328 47.3132886

Narsiah, S. (2018). Pengaruh Philanthropy Disclosure terhadap Nilai Perusahaan dengan Profitabilitas sebagai Variabel Pemoderasi. E-Jurnal Akuntansi, 13(1), 1146-1170.

https://doi.org/10.24843/EJA.2018. v23.i02.p13

Nasri, U. (2011). Shalat Ditinjau Dari Sudut Pandang Pendidikan, Sosial Dan Politik. 44-61.

Nurlaeli Mafrukha. (2009). Pengaruh Shalat Dhuha Terhadap Ketenangan Jiwa Siswa Ms Negeri 1 Waru Sidoarjo. IAIN Sunan Ampel.

Pan, F. (2020). Time Course of Lung Changes at Chest $\{\mathrm{CT}\}$ during Recovery from Coronavirus Disease 2019 (\{COVID\}-19).
Radiology, 295(3), 715-721. https://doi.org/10.1148/radiol.20202 00370

PERGUB. (2020). Peraturan Gubernur Provinsi Daerah Khusus Ibukota Jakarta. Corona.Jakarta.Go.Id, 7, 583-606.

https://corona.jakarta.go.id/storage/ documents/peraturan-gubernurnomor-33-tahun-2020-tentangpelaksanaan-psbb-dalampenanganan-covid-19-di-provinsidki-jakarta-5e987d4687853.pdf

Presiden Republik Indonesia. (2020). Peraturan Pemerintah Nomor 21 Tahun 2020 tentang Pembatasan Sosial Berskala Besar Dalam Rangka Percepatan Penanganan Coronavirus Disease 2019/COVID19. 2019(022868), 8 .

Rahim, R. A., Jalaludin, F. W., \& Tajuddin, K. (2011). The importance of corporate social responsibility on consumer behaviour in Malaysia. Asian

Academy of Management Journal, 16(1), 119-139.

Ridho, A. (2019). Implikasi Kualitas Shalat Subuh dalam Kehidupan 
INTIQAD: JURNAL AGAMA DAN PENDIDIKAN ISLAM

ISSN 1979-9950 (print) || ISSN 2598-0033 (online), http://jurnal.umsu.ac.id/index.php/intiqad DOI: 10.30596/intiqad.v12i2.5195

Vol. 12, No. 2 (December 2020)

Remaja ( Studi Fenomenologi Pada Remaja Tarbiyah ) ( Studi Fenomenologi Pada Remaja Tarbiyah ). Jurnal Nalar, 8(1).

Sarstedt Marko, \& Schloderer Matthias Peter. (2010). Developing a measurement approach for reputation of non-profit organizations. International Journal of Nonprofit and Voluntary Sector Marketing, 15(4), 276-299. https://doi.org/10.1002/nvsm

Schuyt, T., Bekkers, R., \& Smit, J. (2010). The Pilantropy Scale: a sociological perspective in measuring new forms of pro social behaviour. Society, 8(1), 9-11.

Shihab, M. Q. (2009). Membumikan AlQur'an Fungsi dan Peran Wahyu Dalam Kehidupan Masyarakat (I. A. Fauzi (ed.); ketiga). MIZAN.

World Health Organization. (2020).
Situation Report 82. Coronavirus Disease 2019 (COVID-19), 2019 (April), 2633.

https://doi.org/10.1001/jama.2020.2 633

Yayuk Hidayah, Nufikha Ulfah, S. (2019). JPK : Jurnal Pancasila dan Kewarganegaraan. Jurnal Pancasila Dan Kewarganegaraan, 4(2), 22-33. https://doi.org/10.24269/jpk.v4.n2.2 019 